IZA DP No. 10162

Population Aging in India: Facts, Issues, and Options

Arunika Agarwal

Alyssa Lubet

Elizabeth Mitgang

Sanjay Mohanty

David E. Bloom

August 2016

Forschungsinstitut

zur Zukunft der Arbeit

Institute for the Study

of Labor 


\title{
Population Aging in India: Facts, Issues, and Options
}

Arunika Agarwal

Harvard T.H. Chan School of Public Health

Alyssa Lubet

Harvard T.H. Chan School of Public Health

Elizabeth Mitgang

Harvard T.H. Chan School of Public Health

\author{
Sanjay Mohanty \\ International Institute for Population \\ Sciences
}

\author{
David E. Bloom
}

Harvard T.H. Chan School of Public Health

and IZA

\section{Discussion Paper No. 10162 \\ August 2016}

\author{
IZA \\ P.O. Box 7240 \\ 53072 Bonn \\ Germany \\ Phone: +49-228-3894-0 \\ Fax: +49-228-3894-180 \\ E-mail: iza@iza.org
}

Any opinions expressed here are those of the author(s) and not those of IZA. Research published in this series may include views on policy, but the institute itself takes no institutional policy positions. The IZA research network is committed to the IZA Guiding Principles of Research Integrity.

The Institute for the Study of Labor (IZA) in Bonn is a local and virtual international research center and a place of communication between science, politics and business. IZA is an independent nonprofit organization supported by Deutsche Post Foundation. The center is associated with the University of Bonn and offers a stimulating research environment through its international network, workshops and conferences, data service, project support, research visits and doctoral program. IZA engages in (i) original and internationally competitive research in all fields of labor economics, (ii) development of policy concepts, and (iii) dissemination of research results and concepts to the interested public.

IZA Discussion Papers often represent preliminary work and are circulated to encourage discussion. Citation of such a paper should account for its provisional character. A revised version may be available directly from the author. 


\section{ABSTRACT \\ Population Aging in India: Facts, Issues, and Options*}

India, one of the world's two population superpowers, is undergoing unprecedented demographic changes. Increasing longevity and falling fertility have resulted in a dramatic increase in the population of adults aged 60 and up, in both absolute and relative terms. This change presents wide-ranging and complex health, social, and economic challenges, both current and future, to which this diverse and heterogeneous country must rapidly adapt. This chapter first lays out the context, scope, and magnitude of India's demographic changes. It then details the major challenges these shifts pose in the interconnected areas of health, especially the massive challenges of a growing burden of noncommunicable diseases; gender, particularly the needs and vulnerabilities of an increasingly female older adult population; and income security. This chapter also presents an overview of India's recent and ongoing initiatives to adapt to population aging and provide support to older adults and their families. It concludes with policy recommendations that may serve as a productive next step forward, keeping in mind the need for urgent and timely action on the part of government, private companies, researchers, and general population.

JEL Classification: J11, J14, N30

Keywords: population aging, economic demography, longevity

Corresponding author:

David E. Bloom

Department of Global Health and Population

Harvard T. H. Chan School of Public Health

665 Huntington Avenue

Boston, Massachusetts 02115

USA

E-mail: dbloom@hsph.harvard.edu

\footnotetext{
* Research reported in this Working Paper was supported by the National Institute on Aging, National Institutes of Health, under award number R01 AG042778.
} 


\section{Introduction}

India, one of the world's two population superpowers, is undergoing unprecedented demographic changes. Increasing longevity and falling fertility have resulted in a dramatic increase in the population of adults aged 60 and up, in both absolute and relative terms. This change presents wide-ranging and complex health, social, and economic challenges, both current and future, to which this diverse and heterogeneous country must rapidly adapt. This chapter first lays out the context, scope, and magnitude of India's demographic changes. It then details the major challenges these shifts pose in the interconnected areas of health, especially the massive challenges of a growing burden of noncommunicable diseases; gender, particularly the needs and vulnerabilities of an increasingly female older adult population; and income security. This chapter also presents an overview of India's recent and ongoing initiatives to adapt to population aging and provide support to older adults and their families. It concludes with policy recommendations that may serve as a productive next step forward, keeping in mind the need for urgent and timely action on the part of government, private companies, researchers, and general population.

\section{Demography: India's Changing Population Landscape}

India's population of 1.31 billion, the second largest globally, comprises $17 \%$ of the world's total (United Nations 2015), and the United Nations Population Division estimates that India's population will in fact overtake China's by 2028. As India's population grows, its expanding share of older adults is particularly notable. Currently, the growth rate of the number of older individuals (age 60 and older) is three times higher than that of the population as a whole (Giridhar, Sathyanarayana et al. 2014).

Three dominant demographic processes drive the growing share of older Indians: declining fertility rates due to improved access to contraceptives, increasing age at marriage, particularly among women, and declining infant mortality; increasing longevity because of advances in medicine, public health, nutrition, and sanitation; and large cohorts advancing to older ages (Bloom, Hu et al. 2014). India's total fertility rate has decreased from 5.9 in 1950 to 2.3 in 2013 and is projected to drop further to 1.88 by 2050, which is below the replacement level. Life expectancy at birth has improved vastly over the last few decades, increasing from 36.2 years in 1950 to 67.5 years in 2015 and projected to rise to 75.9 years by 2050 (see Figure 1) (United Nations 2015). Even more significant in its implications for population aging, life expectancy at age 60 has also increased dramatically, rising from about 12 years in 1950 to 18 years in 2015 and projected to rise further to more than 21 years by 2050 (see Figure 1). Average Indian life expectancy at age 80 has likewise increased significantly, from about 5 years in 1950 to more than 7 years at the present time. By the middle of this century, it is predicted to rise to 8.5 years (United Nations 2015). 
Figure 1. Steadily increasing life expectancies at older ages

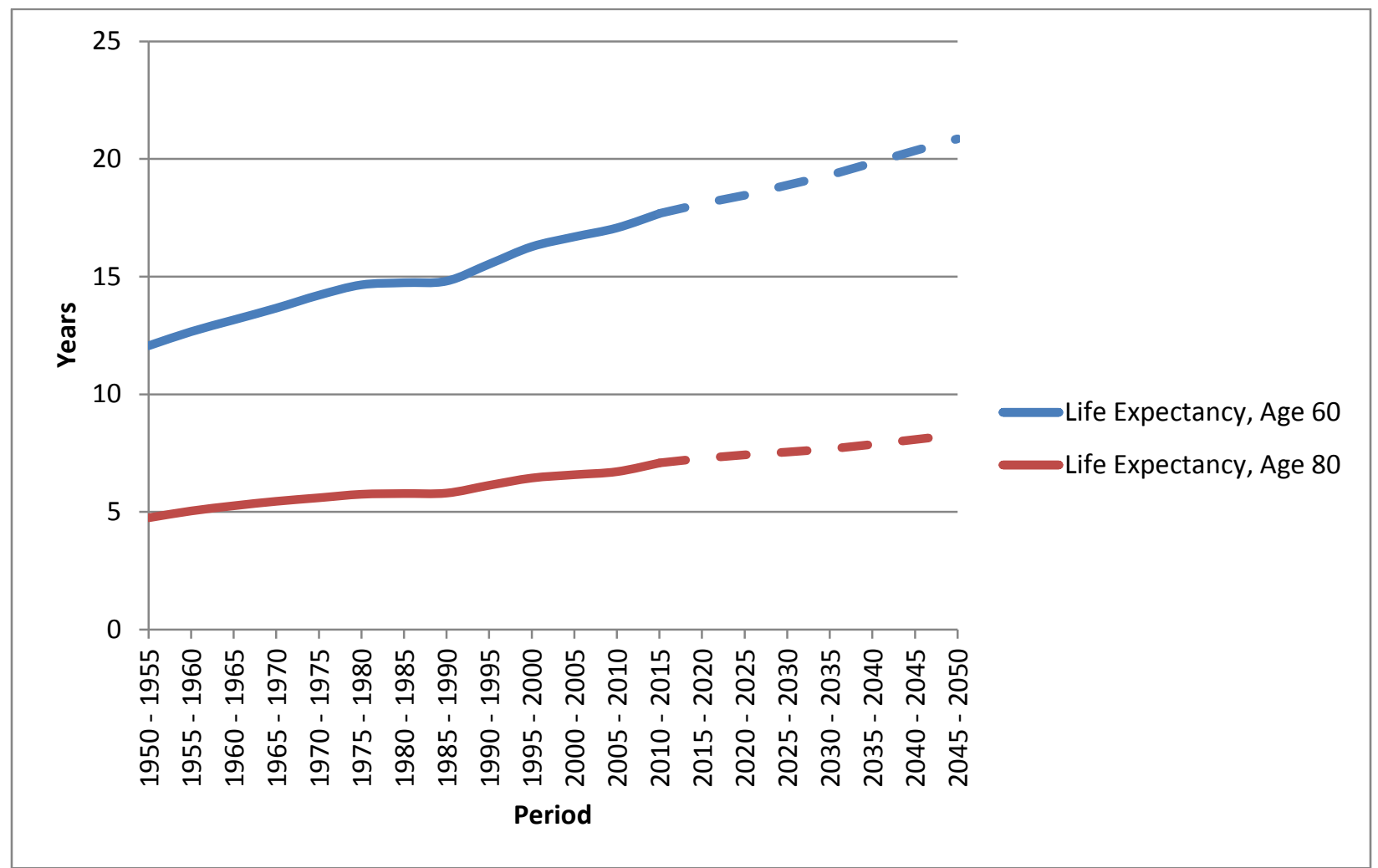

Source: (United Nations 2015); dashed lines represent projected life expectancy

However, the progress that increasing life expectancy represents comes with the challenge of a burgeoning older population. In India, the population share of adults 60 and up grew from 5.4\% in 1950 to $9 \%$ today (Figure 2) - in absolute number of individuals, this represents an almost six-fold increase, from 20.3 million in 1950 to more than 116 million today. For comparison, this population increase of 95.7 million people is greater than the entire individual populations of all but 13 countries worldwide ${ }^{1}$. Under a medium-fertility scenario, the United Nations Population Division projects that adults 60 and over will comprise 19\% of India's total population by 2050 - more than 324 million individuals, which is more than the current populations of all but five of the world's nations. In terms of absolute numbers of adults 60 and older, India is currently second only to China, a standing that will likely remain constant over the next several decades (see Table 1). Meanwhile, the proportion of the "oldest old" adults aged 80 and older has more than doubled over the past 65 years, from $0.4 \%$ of the total population in 1950 to $0.9 \%$ in 2015 , and is projected to reach nearly $3 \%$ of the population—almost 48 million individuals_-by

\footnotetext{
${ }^{1}$ These countries are, as of June 2015: China (1.38 billion), India (1.31 billion), United States of America (322 million), Indonesia (258 million), Brazil (208 million), Pakistan (189 million), Nigeria (182 million), Bangladesh (161 million), Russian Federation (143 million), Mexico (127 million), Japan (127 million), Philippines (101 million), and Ethiopia (99.4 million) (United Nations (2015). World Population Prospects: The 2015 Revision. United Nations Deptartment of Economic and Social Affairs Population Division. Geneva.
} 
2050 (United Nations 2015). ${ }^{2}$ The dramatic and massive nature of these current and ongoing demographic shifts indicates that the population-aging challenges India faces are sure to occur on an enormous scale.

Figure 2. The number of older Indians is growing rapidly as a proportion of the country's population

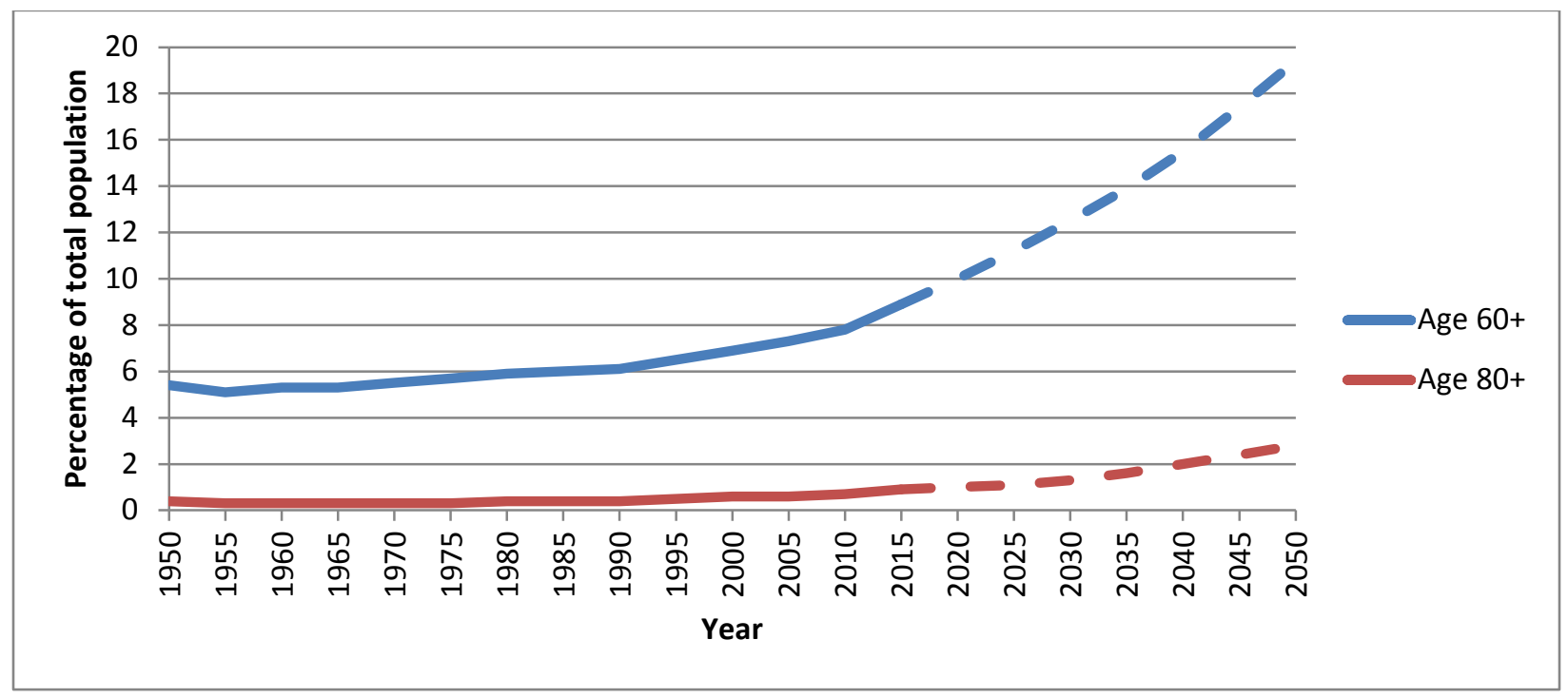

Source: (United Nations 2015); dashed lines represent projections under a medium-fertility scenario

Table 1. Countries with the greatest absolute number of adults 60+, 2015 and 2050

\begin{tabular}{|l|l|l|l|}
\hline 2015 & Adults 60+ (thousands) & Country & Adults 60+ (thousands) \\
\hline Country & 209,240 & 1. China & 491,533 \\
\hline 1. China & $\mathbf{1 1 6 , 5 5 3}$ & 2. India & $\mathbf{3 3 0 , 0 4 3}$ \\
\hline 2. India & 66,545 & 3. United States & 108,326 \\
\hline 3. United States & 41,873 & 4. Brazil & 69,882 \\
\hline 4. Japan & 28,730 & 5. Indonesia & 61,896 \\
\hline 5. Russian Federation & &
\end{tabular}

Source: (United Nations 2015); medium-fertility scenario

\section{Health: the Challenges of the Noncommunicable Disease Burden and Multimorbidity}

As India's population structure changes, so does its health profile. This is especially true for noncommunicable diseases (NCDs). NCDs include cardiovascular diseases, cancers, chronic respiratory diseases, diabetes, and eyesight conditions, the prevalence of which all increase with age. While infectious, nutritional, maternal, and perinatal conditions have traditionally represented the greatest health threats in India, the country now faces a "triple burden of disease" comprising both infectious and chronic conditions and violence and injury-particularly violence against women and girls (Bloom, CafieroFonseca E.T. et al. 2014). The chronic disease corner of this triangle has been growing increasingly

\footnotetext{
${ }^{2}$ When discussing the scope and nature of the challenges of population aging, differentiating the "old" (60+) from the "oldest old" $(80+)$ is important and helpful, as the needs and capacities of those in their 80s and older tend to differ significantly from those in their 60 s and 70 s.
} 
substantial; in the past three decades, NCDs have surpassed infectious, nutritional, maternal, and perinatal conditions as a cause of death, both in absolute numbers and percentages. Noncommunicable diseases, mainly cardiovascular illnesses, cancers, and chronic respiratory diseases, have likewise surpassed these other conditions in the number of annual DALYs ${ }^{3}$ (Table 2) (Institute for Health Metrics and Evaluation 2014).

Table 2. India's growing NCD burden

\begin{tabular}{|l|l|l|l|l|l|l|}
\hline & $\mathbf{1 9 9 0}$ & & & 2013 & & \\
\hline Disease category & $\begin{array}{l}\text { Number } \\
\text { of deaths }\end{array}$ & $\begin{array}{l}\text { Percentage } \\
\text { of all } \\
\text { deaths }\end{array}$ & $\begin{array}{l}\text { Number of } \\
\text { DALYs } \\
\text { (thousands) }\end{array}$ & $\begin{array}{l}\text { Number } \\
\text { of deaths }\end{array}$ & $\begin{array}{l}\text { Percentage } \\
\text { of all } \\
\text { deaths }\end{array}$ & $\begin{array}{l}\text { Number of } \\
\text { DALYs } \\
\text { (thousands) }\end{array}$ \\
\hline $\begin{array}{l}\text { Noncommunicable } \\
\text { diseases }\end{array}$ & $3,702,920$ & 40 & 173,999 & $5,312,560$ & 53 & 253,629 \\
\hline $\begin{array}{l}\text { Cardiovascular } \\
\text { diseases }\end{array}$ & $1,215,810$ & 13 & 31,813 & $2,095,930$ & 21 & 48,794 \\
\hline Cancers & 433,134 & 5 & 13,193 & 663,032 & 7 & 19,094 \\
\hline $\begin{array}{l}\text { Chronic respiratory } \\
\text { diseases }\end{array}$ & $1,115,340$ & 12 & 33,322 & $1,176,740$ & 12 & 35,880 \\
\hline $\begin{array}{l}\text { Infectious, } \\
\text { nutritional, } \\
\text { maternal, } \\
\text { perinatal } \\
\text { conditions }\end{array}$ & $4,807,890$ & 52 & 350,464 & $3,483,130$ & 35 & 221,818 \\
\hline
\end{tabular}

Source: (Institute for Health Metrics and Evaluation 2014)

The prevalence of mental illness, another prominent NCD, is also rising as the population ages. In 2013, mental health and substance abuse disorders accounted for an estimated 5.5\% of total morbidity in the country, some 27 million DALYs. This represents a change of more than 2 percentage points from 1990, when mental health and substance abuse disorders accounted for an estimated 3\% of all morbidity (Institute for Health Metrics and Evaluation 2014). Mental illnesses and substance abuse disorders have also been increasing among older age groups: between 1990 and 2013, mental illness and substance abuse disorders rose from $2.8 \%$ to $4 \%$ of the total morbidity burden among adults 50-69 years of age. Among adults 70 and older, the increase in the same period was from $1.4 \%$ to $1.7 \%$ (Institute for Health Metrics and Evaluation 2014).

Although reliable data on the prevalence of mental illnesses can be difficult to acquire due to social stigma and lack of trained mental health professionals in many communities, particularly in lowerincome countries, evidence indicates that the burden of mental illness in India is far-reaching and pervasive in nature. A study in India's southern states reports that the prevalence of mental illness among older adults may be as high as $27 \%$, with depression, anxiety, bipolar disorder, dementia, and alcohol dependence predominating (Reddy, Gupta et al. 2013). Meanwhile, data from India's National Sample

\footnotetext{
${ }^{3}$ Disability-adjusted life years (DALYs) are a measure of healthy life used by the World Health Organization and other health-monitoring bodies.
} 
Survey (NSS) suggest a significant positive correlation between mental illness prevalence and age, especially in rural areas (Lakhan and Ekundayo 2015).

This growing burden of both physical and mental chronic illnesses has the potential to translate into staggering economic losses; a 2014 World Economic Forum report predicts that NCDs may cost India as much as \$4.3 trillion in productivity losses and healthcare expenditure between 2012 and 2030, a figure that is twice the country's annual GDP (Bloom, Cafiero-Fonseca E.T. et al. 2014). Deaths from cardiovascular disease alone may cost India more in terms of years of healthy working life than any other country in the world (Srinath Reddy, Shah et al. 2005). While one theory about the future path of aging suggests "compression of morbidity"-the reduction of the portion of the human lifespan spent living with disease and disability (Fries 1980) — evidence exists that years of disease and disability are in fact increasing for older Indians as lifespans grow longer (Arokiasamy and Yadav 2014).

Fueling the growing burden of NCDs is an increase in the prevalence of four major chronic disease risk factors: tobacco use, obesity, physical inactivity, and alcohol consumption, the first three of which are particularly pertinent to older Indian adults. According to the second Indian Human Development Survey (IHDS-II) conducted in 2011-2012, more than 10\% of respondents age 60 and up reported that they smoked cigarettes "sometimes" or "daily." A far greater number, however, reported smoking bidis (inexpensive hand-rolled tobacco cigarettes) or hookah: about 6\% of 60+ IHDS respondents reported that they smoked bidis or hookah sometimes, while $36 \%$ reported smoking them daily. Far more common was the use of chewing or smokeless tobacco-highly popular in South Asian countries - among older respondents, with nearly 60\% reporting occasional or daily use (Desai, Dubey et al. 2015). In the first wave of the World Health Organization's Study on Global Ageing and Adult Health (SAGE) survey, conducted in several low- and middle-income countries including India, China, Ghana, and the Russian Federation, rates of daily smoking among 50+ Indian adults were as high as 46.7\% -- the highest of all countries surveyed (Wu, Guo et al. 2015).

In addition to high rates of smoking, overweight and obesity are also rising among older adults in India. According to anthropometric data collected by the IHDS-II, some $63 \%$ of adults 65 and up were classed as overweight or obese, with overweight defined as having a body mass index (BMI) of 25-29.9 and obesity defined as a BMI of 30 or higher (Desai, Dubey et al. 2015). Obesity is on the rise in India in part due to a combination of readily available high-fat-content food products and increasingly sedentary lifestyles. In the 2010 Longitudinal Aging Study in India (LASI pilot) study of about 1,500 older adults (adults 45 and up in rural and urban areas and their spouses irrespective of age) in four states, a full 69\% of respondents reported getting no physical exercise; lack of exercise increased with age and was significantly more prevalent among females than males (Arokiasamy, Bloom et al. 2012). This finding is consistent with the anthropometric data gathered in the pilot study, in which $29 \%$ of female and $20 \%$ of male respondents had BMIs of 25 or above. In addition, the median systolic blood pressure reading among study participants was 130 and the median diastolic reading was 83, both in the pre-hypertensive range; one in three participants were found to have hypertension proper with a systolic of 150 and above and a diastolic of 90 or above, with a large proportion of these respondents previously aware of their hypertensive status (Bloom, Hu et al. 2014).

India's recent NCD morbidity and mortality increases are even more pronounced among older adults than in the general population. In 2013, an estimated 2.4 million deaths of Indian adults aged 50 to 69 were 
due to NCDs-nearly three quarters of all deaths in this age group and nearly half of these due to cardiovascular disease. Among adults 70 and up, NCDs caused some 2.7 million deaths, 93\% of the total (Institute for Health Metrics and Evaluation 2014). Exacerbating the problem is the issue of multimorbidity, which complicates the management of NCDs considerably, especially because in India, as in many other countries, most health programs have a vertical, disease-specific approach that targets a single set of outcomes rather than dealing with the health of the individual holistically (Pati, Agrawal et al. 2014). Survey data show that the prevalence of multimorbidity increases sharply with age. The World Health Organization's Study on Global Ageing and Adult Health (SAGE) in India found 30.6\% of respondents 70 and older reported having more than one chronic condition, compared with just $1.3 \%$ of individuals 18-29 years of age (Pati, Agrawal et al. 2014). Meanwhile, results from the IHDS-II indicate that about $7.3 \%$ of respondents 65 and up reported having two or more chronic conditions, compared with about $1.3 \%$ of adults between the ages of 18 and 65 (however, the IHDS-II, which is not targeted specifically at older adults, did not collect data, measured or self-reported, on certain NCDs that frequently afflict older adults, such as stroke, musculoskeletal disorders, eyesight conditions other than cataracts, or chronic respiratory diseases other than asthma, and thus did not capture all instances of multimorbidity) (Desai, Dubey et al. 2015). Although further studies are needed, India's aging-fueled multimorbidity increase will most likely mean an even more costly and complicated illness burden.

Although the reported burden of chronic illness is high, many NCDs affecting older adults remain undiagnosed due to lack of access to health education, services, and financial resources. In a crosssectional study conducted in 10 Indian states in 2009-2010, some 15\% of about 5,400 diabetic individuals and 33\% of over 7,200 hypertensive individuals were previously unaware of their health condition(s) (Joshi, Saboo et al. 2012). The International Diabetes Federation gives an even higher estimate, positing that some 33\% of adult diabetics in India remain undiagnosed (International Diabetes Federation 2012).

Overall, the country will clearly need to address the changes in its healthcare needs and priorities accompanying the demographic shift that is already underway.

\section{Population Aging and Gender Issues}

Accompanying the aging of the Indian population is increasing feminization in older age groups, which brings its own unique issues and challenges. Although average life expectancy has increased dramatically in India, it has not risen equally for males and females. Although women's life expectancy at birth has long exceeded men's, as in most countries globally, the life expectancy gender gap has been widening in India. In 1950-1955, Indian women's life expectancy at age 60 exceeded men's by 0.07 years; by 20102015, this gap had doubled, and by 2050-2055 it is projected to reach 2 years (see Table 3). Meanwhile, although the male-female gap in life expectancy at age 80 fell between 1950 and the present, it is expected to rise again over the next 40 years (United Nations 2015).

Table 3. Trends in male-female differences in life expectancy at ages 60 and 80 in India, 1950-2055

\begin{tabular}{|l|l|l|l|l|l|l|}
\hline Year & $\begin{array}{l}\text { Male life } \\
\text { expectancy, } \\
\text { age 60 }\end{array}$ & $\begin{array}{l}\text { Female life } \\
\text { expectancy, } \\
\text { age 60 }\end{array}$ & $\begin{array}{l}\text { Life } \\
\text { expectancy } \\
\text { sex gap, age } \\
60\end{array}$ & $\begin{array}{l}\text { Male life } \\
\text { expectancy, } \\
\text { age 80 }\end{array}$ & $\begin{array}{l}\text { Female life } \\
\text { expectancy, } \\
\text { age 80 }\end{array}$ & $\begin{array}{l}\text { Life } \\
\text { expectancy } \\
\text { sex gap, age } \\
80\end{array}$ \\
\hline
\end{tabular}




\begin{tabular}{|l|l|l|l|l|l|l|}
\hline $\mathbf{1 9 5 0 - 1 9 5 5}$ & 11.7 & 12.4 & -0.07 & 4.2 & 5.2 & -1.0 \\
\hline $\mathbf{1 9 8 0}-\mathbf{1 9 8 5}$ & 14.1 & 15.5 & -1.4 & 5.3 & 6.2 & -0.9 \\
\hline $\mathbf{2 0 1 0 - 2 0 1 5}$ & 17.0 & 18.4 & -1.4 & 6.8 & 7.2 & -0.4 \\
\hline $\mathbf{2 0 3 0 - 2 0 3 5}$ & 18.5 & 20.1 & -1.6 & 7.5 & 7.9 & -0.4 \\
\hline $\mathbf{2 0 5 0 - 2 0 5 5}$ & 20.4 & 22.4 & -2.0 & 8.0 & 8.9 & -0.9 \\
\hline
\end{tabular}

Source: (United Nations 2015); 2030-2055 figures are projections based on a medium-fertility scenario

This growing longevity gap between the sexes implies that India's older adult population is growing increasingly female. In 1950, India's population of female adults 60 and up was 50.8\%. In 2015, despite a high overall male/female sex ratio throughout the latter half of the twentieth century (about 106107 males per 100 females), this proportion has grown to approximately $52.5 \%$ and is projected to reach about $53 \%$ by 2050 under a medium-fertility scenario. In the oldest old segment of adults 80 and up, the proportion of females is projected to increase from the current $55 \%$ to $56 \%$ by 2050 . Although the change in percentage points is somewhat small, in absolute terms it represents hundreds of thousands of individuals. In comparison, about $51 \%$ of $60+$ adults in China, the only country more populous than India, are currently female; by 2050, this proportion will actually decline by about $0.02 \%$. The proportion of female 60+ adults in Brazil and the United States are also projected to decline, rather than increase, in the next 35 years (Brazil: from 56\% to 55\%; United States: from 54\% to 53\%) (United Nations 2015).

This national trend obscures a great deal of heterogeneity across Indian states. Different male and female life expectancies and life expectancy gaps in different states and regions of the country imply that states will have dramatically dissimilar sex divisions among their older adult populations. Table 4 shows this inter-state spread, comparing state-level sex differences in life expectancy at age 60 in India's 17 most populous states. The somewhat large range between the half-year difference in Bihar to the more than four-year gap in Rajasthan suggests that different states may see highly different gender profiles in their populations of older adults in the years to come, which will necessitate state and local governments to tailor their policies and programs appropriately.

Table 4. Differences in years between male and female life expectancy at age 60 in 2011 in the 17 most populous states of India, 2011

\begin{tabular}{|l|l|l|l|}
\hline State & Male & Female & Difference \\
\hline Rajasthan & 16.9 & 21.0 & $\mathbf{- 4 . 1}$ \\
\hline Kerala & 18.0 & 21.6 & $\mathbf{- 3 . 6}$ \\
\hline Jammu and Kashmir & 19.1 & 22.3 & $\mathbf{- 3 . 2}$ \\
\hline Haryana & 17.6 & 20.5 & $\mathbf{- 2 . 9}$ \\
\hline Gujarat & 17.1 & 19.8 & $\mathbf{- 2 . 7}$ \\
\hline Assam & 15.4 & 17.9 & $\mathbf{- 2 . 5}$ \\
\hline Andhra Pradesh & 16.8 & 19.2 & $\mathbf{- 2 . 4}$ \\
\hline Madhya Pradesh & 15.4 & 17.6 & $\mathbf{- 2 . 2}$ \\
\hline Himachal Pradesh & 18.3 & 21.0 & $\mathbf{- 2 . 7}$ \\
\hline Karnataka & 16.8 & 19.0 & $\mathbf{- 2 . 2}$ \\
\hline Uttar Pradesh & 15.8 & 18.0 & $\mathbf{- 2 . 2}$ \\
\hline National Average & $\mathbf{1 7 . 0}$ & $\mathbf{1 8 . 4}$ & $\mathbf{- 1 . 4}$ \\
\hline
\end{tabular}




\begin{tabular}{|l|l|l|l|} 
West Bengal & 16.9 & 18.7 & $\mathbf{- 1 . 8}$ \\
\hline Punjab & 19.3 & 21.0 & $\mathbf{- 1 . 7}$ \\
\hline Tamil Nadu & 17.2 & 18.9 & $\mathbf{- 1 . 7}$ \\
\hline Maharashtra & 17.9 & 19.5 & $\mathbf{- 1 . 6}$ \\
\hline Odisha & 16.8 & 17.6 & $\mathbf{- 0 . 8}$ \\
\hline Bihar & 17.0 & 17.5 & $\mathbf{- 0 . 5}$ \\
\hline
\end{tabular}

Sources: (United Nations 2015) (National Average); (Government of India 2013), (Government of India 2015) (State estimates); authors' computation from data

One of the most important implications of an increasingly female older adult population in India-including variations in the extent of this trend across states-will be the prevalence of widowhood among women. Higher female life expectancies and higher average male age at first marriage are sharply increasing India's population of widowed females. Women whose husbands have died may also spend more years of their lives as widows. In 2012, for example, only 8\% of Indian males aged 60 to 64 were widowed, compared with $35 \%$ of females in this age group. Among adults 80 and older, a majority of females, more than $60 \%$, had been widowed, compared with just $27 \%$ of males (Desai, Dubey et al. 2015). This is highly significant because in many Indian communities, and particularly under traditional Hindu law, widowed women have historically suffered from social stigmatization and discrimination, although evidence exists for improvement in the treatment of widows in the country as a whole (Kadoya and Yin 2012). Most notably, widowed females may suffer from income insecurity due to inheritance traditions that favor sons over daughters and insecurity in their living arrangements (Dey, Nambiar et al. 2012, Sathyanarayana, Kumar et al. 2014). Evidence also indicates that Indian female widows aged 60 and up suffer from morbidity due to communicable and noncommunicable diseases at a significantly higher rate-13\% more - than do male widowers in the same age group. Despite this, however, older female widows are also significantly less likely to engage in health care seeking behavior (Agrawal and Keshri 2014).

In addition to the perils of widowhood, older women in India are significantly disadvantaged in terms of education and literacy relative to both their male contemporaries and to women and men in younger age groups. According to the IHDS-II, as of 2012, only about 22\% of Indian women aged 65 or over were literate, compared with $55 \%$ of men in this age group. This disparity is especially striking compared with literacy rates for adolescents and adults aged 15 to 64: a nearly equal 63\% for females and $64 \%$ for males, which reflects more recent improvements in educational access and opportunity. The education gap in older age groups also bears out in years of schooling. While men and women aged 1564 have nearly identical average years of schooling -- with females' years of education actually slightly higher than males' (females averaged 2.8 and males 2.7) - a pronounced disparity exists among those aged 65 and up. Among older Indian adults, women average only one year of education compared with four for their male counterparts (Desai, Dubey et al. 2015). Because of these disparities in education, older Indian women may be less able to learn about issues such as health risk factors and government benefits and less able to advocate for themselves effectively.

Economic security for older Indian women-particularly widowed and unmarried women, but also for women in general-is also a major concern. Labor force participation among women is very low, and a majority of women depend on their families for economic support (Government of India 2011). Moreover, women in India have historically not owned assets due to the nation's patriarchal inheritance 
system in which assets and property are kept within a family's male lineage. Not until a 2005 amendment to national property law have women been entitled to equal property inheritance rights (Government of India 2005). Policy that strives to ensure financial security for both older men and women must be committed to promoting and defending these newly legalized inheritance rights.

Because of ongoing age and gender demographic shifts; considerable heterogeneity in sex-based life expectancy gaps; and prevalence of widowhood across Indian states, aging- and gender-related issues will likely converge as India's population continues to age over the next several decades. Policy changes and programs must pay attention to the special needs and situations of older women, particularly widows, to ensure the wellbeing of all of the country's older population.

\section{Income Security: Changing Patterns and Lack of a Safety Net}

Another major challenge of population aging in India is income and housing security for older adults. This is due in part to a changing social and economic landscape in which the traditional family support system is breaking down in the households of many older adults. In India, as in many East and South Asian countries, family has traditionally served as the prime source of support for aging adults, with sons responsible for caring for their parents. However, evidence indicates that this support system has been declining due to factors such as increased urbanization and mobility; a 2011 United Nations Population Fund (UNFPA) survey carried out in selected states revealed that about a fifth of 60+ respondents lived alone or solely with a spouse. The main reasons cited for living without children were having no children, or children living in a different locality due to education, work, or marriage, rather than due to personal preference. Furthermore, only $14 \%$ of these single-generation, older-adult households received financial support from friends or relatives (Alam, James et al. 2012).

Workforce participation patterns and employment sectors among older Indian adults are also significant for multiple reasons. First, employment and workforce attachment data give information about income and income security for India's aging population. Estimates from India's most recent census indicate that $42 \%$ of adults 60 and up and $22 \%$ of adults 80 and up still participate in the workforce (Government of India 2011). The UNFPA survey of older Indians found that about $24 \%$ of India's nearly 10,000 respondents aged 60+ remained in the workforce and that a large proportion of these respondents were working at a relatively high intensity level of at least six months out of the year or more than four hours a day. Rates of workforce participation among older adults were markedly higher in rural (47\%) than in urban areas (29\%); were much higher for males than for females (as is the case at all ages-see Table 5); and varied significantly across states, from $26.8 \%$ in Goa to $53.5 \%$ in Nagaland. As many Indian individuals experience longer lifespans and better health, an increasing number may choose to continue to work, full time or part time, beyond traditional retirement ages for reasons of enjoyment and intellectual stimulation, or to share their knowledge and experience with younger workers. At the present time, however, more than $70 \%$ of older Indian workers surveyed cited economic necessity, rather than personal preference, as their main reason for remaining in the workforce, indicating a high level of income insecurity (Alam, James et al. 2012).

The second major reason that workforce participation is significant is because only individuals who have worked in the "organized" labor market—-that is, those who have had official employment with employers such as government organizations or private corporations-are eligible to receive pensions after their retirement. An estimated 83\% of India's working population, however, is in the unorganized 
sector and therefore not entitled to receive any pension or retirement benefits in their old age. In total, less than $10 \%$ of the population currently receives a pension of any kind (Uppal and Sarma 2007). India faces an urgent need for social safety net measures that are available to all individuals, regardless of work history.

Table 5. Workforce participation by age, gender, and place of residence (\%)

\begin{tabular}{|l|l|l|l|l|l|l|l|l|l|}
\hline $\begin{array}{l}\text { Age } \\
\text { group }\end{array}$ & \multicolumn{4}{|l|}{ Total } & \multicolumn{3}{l|}{ Rural } & \multicolumn{3}{l}{ Urban } \\
\hline & Total & Male & Female & Total & Male & Female & Total & Male & Female \\
\hline Total & 39.8 & 53.3 & 25.5 & 41.8 & 53.0 & 30.0 & 35.3 & 53.8 & 15.4 \\
\hline $15-59$ & 58.5 & 78.4 & 37.4 & 63.0 & 79.8 & 45.4 & 49.5 & 75.7 & 21.4 \\
\hline $60+$ & 41.6 & 60.4 & 23.4 & 47.1 & 66.4 & 28.4 & 28.5 & 46.1 & 11.3 \\
\hline $70+$ & 29.5 & 45.1 & 14.5 & 33.5 & 50.0 & 17.5 & 19.8 & 33.1 & 7.6 \\
\hline $80+$ & 22.1 & 34.9 & 10.9 & 24.4 & 37.1 & 12.8 & 16.9 & 29.5 & 6.7 \\
\hline & & & & & & & & & \\
\hline
\end{tabular}

Source: (Government of India 2011)

Figure 3. Full-time workforce participation rate by sex and age, 2011

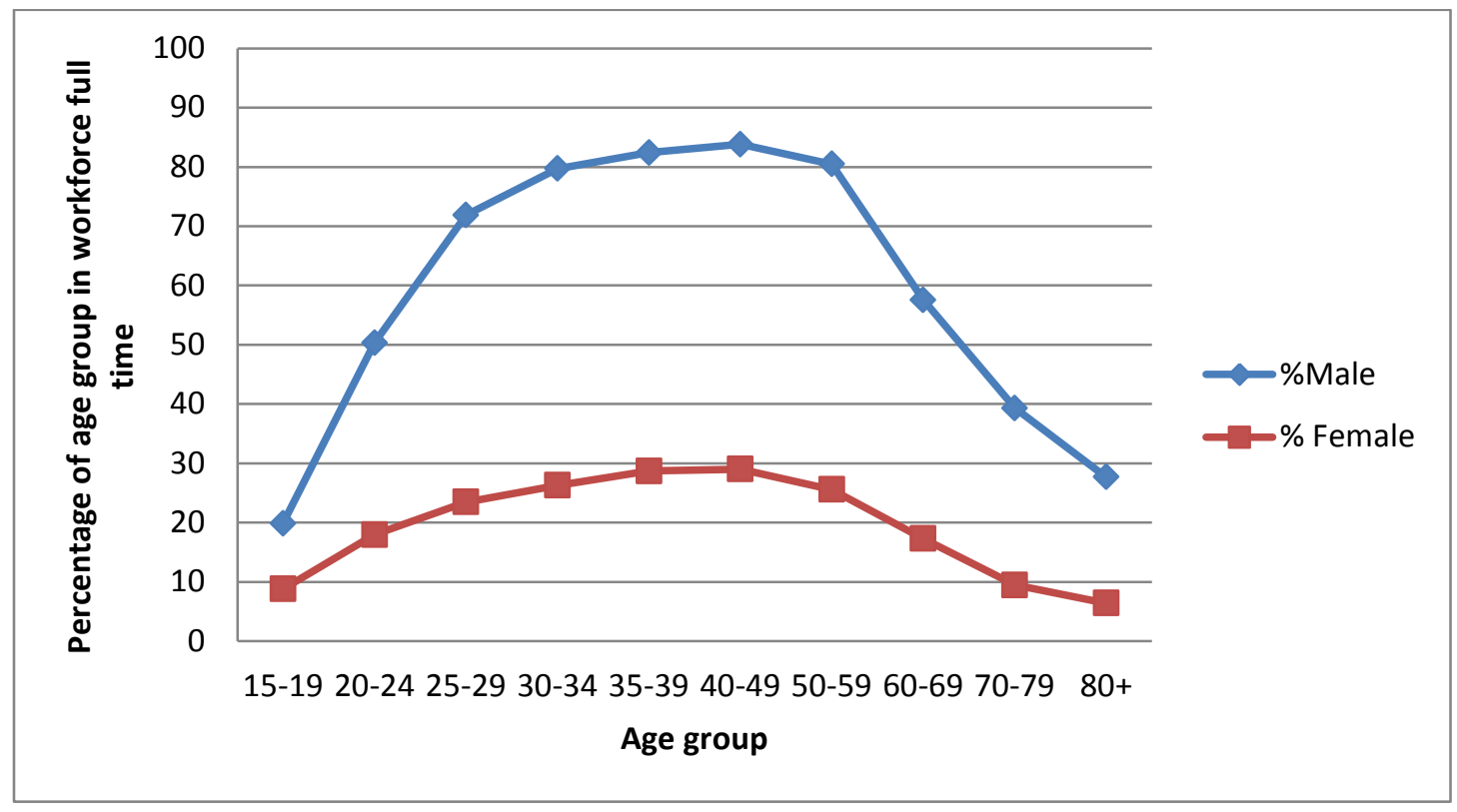

Source: (Government of India 2011)

Income security takes on extra significance with older adults due to rising health care consumption and expenditure. As discussed previously, the prevalence of noncommunicable diseases increases with age, and so, accordingly, does health care spending. Average annual per capita out-of-pocket health spending in India is almost four times as high for older adults (INR 2,890, about US\$43) as among younger adults (INR 770, about US\$11) (Bloom, Mahal et al. 2010). In a country in which the per capita GDP is about $\$ 1,600$ (World Bank 2015), this is hardly an insignificant sum. Moreover, only $17 \%$ of the 
population is covered by health insurance (Bloom, Mahal et al. 2010). Indeed, the 2011 LASI pilot survey found that of about 1,600 adults aged 45 and older, 87\% reported "family" as their primary payment mechanism for health care costs, while only 1\% reported having insurance (Arokiasamy, Bloom et al. 2012). In the absence of health insurance and quality health care infrastructure, catastrophic health care expenditures can easily push older adults into poverty. Health insurance and comprehensive health care policies will also be a crucial component of any national action designed to ensure the income security of India's older adults.

\section{Policy Options: Past Attempts, Future Prospects}

Although the Indian government has proposed several schemes and resolutions to support an aging population, most of these have thus far met with limited success. At the 1991 United Nations General Assembly, member countries adopted the United Nations' Principles for Older Persons, which encourages governments to incorporate the principles of independence, dignity, care, participation, and selffulfillment of the elderly in their national policies and programs (1991). Soon after the declaration, India's Ministry of Social Justice and Empowerment implemented an Integrated Programme for Older Persons (IPOP) in 1992 (Government of India 2015). Under this program, citizens aged 60 years and older are eligible to receive basic amenities such as food, shelter, health care, and other welfare services. The scheme also provides financial assistance to nongovernmental organizations (NGOs), voluntary organizations, and Panchayati Raj (local government) institutions to maintain old-age homes, continuouscare homes, and clinics for older persons.

Since 1992, multiple government ministries across various sectors have implemented initiatives that attempt to provide benefits and security to older adults in India (see Table 6). However, most of these schemes have not yet been implemented nationwide; many state-level governments have failed due to lack of resources and competing priorities. Moreover, in the states where these programs have been implemented, such as Himachal Pradesh, Punjab, West Bengal, Odisha, and Tamil Nadu, the utilization rate remains very low due to lack of public awareness (Alam, James et al. 2012). According to the United Population Fund survey, for example, 78\% of the older adult population was aware of the Indira Gandhi National Old Age Pension Scheme, while some 71\% knew about the Indira Gandhi National Widow Pension Scheme. A mere 39\% of respondents were aware of the Annapurna food scheme. Utilization rates of these schemes are typically below $20 \%$ of eligible individuals (Alam, James et al. 2012), with a wide gap between levels of awareness and levels of use due to factors such as corruption and difficult-tonavigate bureaucracy. Meanwhile, data from the IHDS-II suggest that only about $18 \%$ of adults 60 and up receive any sort of old-age pension and that $15 \%$ of all female widows 60 and older receive a widows' pension (Alam, James et al. 2012).

In late 2015, the World Health Organization announced the development of a Global Strategy and Action Plan on Ageing and designated 2020-2030 as the Decade of Healthy Ageing. Although still in development as a draft, the Global Strategy and Action Plan calls on all countries to "commit to fostering healthy ageing, with action plans in place to maximize functional ability that reach everyone.” Its main strategic objectives include fostering healthy aging, aligning health systems with the needs of older populations, developing long-term care, creating "age-friendly environments," and improving measurement and evaluation. It may provide a promising framework for India to improve and maintain the lives and wellbeing of its aging population in the years to come (World Health Organization 2016). 
Indeed, India's parliament chose to debate the issue in an hour-long session soon after, giving a promising indication that population aging is returning to the fore of the government's agenda.

Table 6. Overview of current programs aimed at older adult welfare in India

\begin{tabular}{|c|c|c|c|}
\hline Sector & Schemes/ Programs & Objectives & $\begin{array}{l}\text { Year of } \\
\text { implement } \\
\text { ation }\end{array}$ \\
\hline \multirow[t]{3}{*}{ Health } & $\begin{array}{l}\text { National Program for } \\
\text { Health Care of Elderly } \\
\text { (NPHCE) }\end{array}$ & $\begin{array}{l}\text {-Community-based primary healthcare } \\
\text { - Strengthening of geriatric health services at district } \\
\text { hospitals/CHC/PHC/sub-centers } \\
\text { - Dedicated facilities at } 100 \text { district hospitals with 10- } \\
\text { bedded ward for the elderly } \\
\text {-Establishing } 8 \text { regional medical institutions for } \\
\text { tertiary-level medical care }\end{array}$ & 2010-2011 \\
\hline & $\begin{array}{l}\text { Rashtriya } \quad \text { Swasthya } \\
\text { Bima Yojana (RSBY) }\end{array}$ & $\begin{array}{l}\text { This scheme provides health insurance coverage for } \\
\text { BPL families, including the elderly. Beneficiaries } \\
\text { under RSBY are entitled to hospitalization coverage } \\
\text { up to Rs. } 30,000 \text { for most diseases that require } \\
\text { hospitalization. }\end{array}$ & 2008 \\
\hline & Private Insurance & $\begin{array}{l}\text { Special health insurance schemes for senior citizens } \\
\text { over } 60 \text { years by various private insurance providers } \\
\text { have been initiated }\end{array}$ & Varies \\
\hline \multirow[t]{2}{*}{$\begin{array}{l}\text { Finance } \\
\text { and } \\
\text { Revenue }\end{array}$} & $\begin{array}{l}\text { Incentives } \quad \text { under } \\
\text { Income Tax Act, } 1961\end{array}$ & $\begin{array}{l}\text { A senior citizen is liable to pay income tax for income } \\
\text { above Rs. } 3 \text { lakh per annum and Rs. } 5 \text { lakh for people } \\
80 \text { years and older; limits are periodically revised. }\end{array}$ & 1961 \\
\hline & Concessions & $\begin{array}{l}\text { Senior citizen concessions in railways- } 40 \% \text { for men } \\
\text { and } 50 \% \text { for women } \\
\text { Air India offers } 50 \% \text { discount to senior citizens (to } \\
\text { above } 63 \text { years old) } \\
\text { Discounted tickets for public road transport. }\end{array}$ & Varies \\
\hline Legal/Law & $\begin{array}{l}\text { Senior Citizen Savings } \\
\text { Scheme }\end{array}$ & $\begin{array}{l}\text { Senior citizens are eligible for tax deduction under } \\
\text { section 80C of the Income Tax Act as well as higher } \\
\text { interest rates for savings accounts at national banks. }\end{array}$ & 2004 \\
\hline \multirow[t]{2}{*}{$\begin{array}{l}\text { Social } \\
\text { Justice and } \\
\text { Empowerm } \\
\text { ent }\end{array}$} & $\begin{array}{l}\text { Maintenance and } \\
\text { Welfare of Parents and } \\
\text { Senior Citizens }\end{array}$ & $\begin{array}{l}\text { Legally obligates children and heirs to provide } \\
\text { maintenance to senior citizens and parents, by } \\
\text { monthly allowance, in addition to caring for elderly } \\
\text { parents. }\end{array}$ & 2007 \\
\hline & $\begin{array}{l}\text { Integrated Program for } \\
\text { Older Persons (IPOP) }\end{array}$ & $\begin{array}{l}\text { Providing basic amenities like shelter, food, medical } \\
\text { care, and entertainment. Financial assistance is } \\
\text { provided to NGOs for maintenance of old-age homes, } \\
\text { respite-care homes, and continuous-care home; mobile } \\
\text { medical units; daycare centers for Alzheimer's } \\
\text { patients; etc. }\end{array}$ & 1992 \\
\hline
\end{tabular}




\begin{tabular}{|c|c|c|c|}
\hline & \begin{tabular}{lr}
\multicolumn{2}{l}{ Old-age pension under } \\
Indira & Gandhi \\
National & Old Age \\
Pension & Scheme \\
(IGNOPS) &
\end{tabular} & $\begin{array}{l}\text { Central government assistance of Rs. } 200 \text { per month to } \\
\text { people in } 60-79 \text { year age group and Rs. } 500 \text { to people } \\
\text { above } 80 \text { years of age belonging to BPL households; } \\
\text { supplemented by state governments in varying } \\
\text { amounts. }\end{array}$ & 2007 \\
\hline & Annapurna Scheme & $\begin{array}{l}\text { Senior citizens } 65 \text { years of age or older who, though } \\
\text { eligible for old-age pension under the National Old } \\
\text { Age Pension Scheme (NOAPS), are not getting the } \\
\text { pension are covered and } 10 \mathrm{~kg} \text { of food grains per } \\
\text { person per month are supplied free of cost under the } \\
\text { scheme. }\end{array}$ & 2000-2001 \\
\hline \multirow[t]{3}{*}{$\begin{array}{l}\text { Rural } \\
\text { Developme } \\
\text { nt }\end{array}$} & $\begin{array}{lr}\text { Indira } & \text { Gandhi } \\
\text { National } & \text { Widow } \\
\text { Pension } & \text { Scheme } \\
\text { (IGNWPS) } & \end{array}$ & $\begin{array}{l}\text { Pension of Rs. } 200 \text { per month to widows in } 40-64 \\
\text { year age group belonging to BPL category }\end{array}$ & 2009 \\
\hline & $\begin{array}{lr}\text { National } & \text { Family } \\
\text { Benefit } & \text { Scheme } \\
\text { (NFBS) } & \end{array}$ & $\begin{array}{l}\text { Central assistance of Rs. } 20,000 \text { provided to a BPL } \\
\text { household on the death of the primary bread earner of } \\
\text { the family who was in the age group of } 18-59 \text { years }\end{array}$ & 1998 \\
\hline & $\begin{array}{lr}\text { Mahatma } & \text { Gandhi } \\
\text { National } & \text { Rural } \\
\text { Employment } & \\
\text { Guarantee } & \text { Act } \\
\text { (MGNREGA) } & \\
\end{array}$ & $\begin{array}{l}\text { The Act guarantees } 100 \text { days of employment in a } \\
\text { financial year to any rural household whose adult } \\
\text { members are willing to do unskilled manual work. }\end{array}$ & 2006 \\
\hline \multirow[t]{2}{*}{$\begin{array}{l}\text { Retirement/ } \\
\text { Pension }\end{array}$} & $\begin{array}{l}\text { National Pension } \\
\text { System (NPS) }\end{array}$ & $\begin{array}{l}\text { The objective is providing retirement income to all } \\
\text { citizens. Initially, NPS was introduced for government } \\
\text { employees. Taking effect 1st May 2009, NPS has } \\
\text { been provided for all citizens of the country, including } \\
\text { unorganized sector workers on a voluntary basis. }\end{array}$ & 2004 \\
\hline & Swavalamban Scheme & $\begin{array}{l}\text { Implemented especially for unorganized workers, } \\
\text { under this program, the government will contribute a } \\
\text { sum of Rs.1,000 to each eligible NPS subscriber who } \\
\text { contributes a minimum of Rs.1,000 and maximum } \\
\text { Rs.12,000 per annum. }\end{array}$ & 2010-2011 \\
\hline
\end{tabular}

Source: (Government of India 2015)

Abbreviations:

CHC: Community Health Center

PHC: Primary Health Center

BPL: Below Poverty Line

Based on the limited success of past and current policies aimed at aging adults, a business-as-usual approach will clearly not be sufficient to manage India's transition. The challenges discussed in this chapter will necessitate multi-sectoral responses, including public and private policy pathways, technological advances, and infrastructural modifications and additions. 


\section{1 - Health and Accessibility}

India must take significant steps to ensure the health of its aging population. A large component of these steps must include programs and policies for the prevention, detection, and treatment of noncommunicable diseases; this is important both for today's population of older adults and for the current generation of younger adults to ensure healthy future aging. To this end, several recent programs, mostly community- and primary-care based, have met with success in this area. One example is the National Programme for Prevention and Control of Cancer, Diabetes, Cardiovascular Diseases, and Stroke (NPCDCS), a government-sponsored screening and prevention program launched as a 2008 pilot program in Karnataka and slated for expansion to at least 10 other states (Government of India Press Information Bureau 2010). The Kidney Help Trust of Chennai, a community-based diabetes screening and prevention program (Mani 2005), and mental health service delivery that utilizes trained lay workers, first tested in Goa (Patel, Weiss et al. 2010), have also shown promise in terms of efficacy and costeffectiveness and are good candidates for scale-up (Bloom, Cafiero-Fonseca E.T. et al. 2014). Meanwhile, increased tobacco taxation, smoking bans, and expansion of public awareness campaigns on the health consequences of smoking will also likely be necessary to mitigate one of the leading NCD risk factors in the country (World Health Organization 2009, Jha, Guindon et al. 2011).

In addition to trying to ameliorate its growing age-associated NCD burden, India must also implement programs designed to meet the special health needs of older adults who are also more susceptible to multimorbidity, which requires holistic and specialized care. The government has taken steps toward this goal in the form of plans to establish two national geriatric centers in Delhi and Chennai and 12 regional geriatric centers in medical institutions across the country (Express News Services 2015). These centers will act as research and academic institutes for geriatric medicine and provide health services to the local older adult population. In addition to these national and regional centers, all of which are located in urban areas, connecting these regional centers to district- and village- level health facilities will be crucial to serve the needs of India's rural population, which still comprises a majority of the country's people in spite of increasing urbanization (United Nations 2014).

Beyond expanding and strengthening networks of health care provision for older adults, a need and an opportunity exist to use technology to aid people living in remote areas, or who have limited mobility. One promising technology application is information and resource "telehealth" call and monitoring centers that could offer health advice and support to aging adults (World Health Organization 2007). Such telehealth or "m-health" models aimed at older adults have already met with some success in higher-income countries (Cimperman, Makovec Brenčič et al. 2013), while telehealth call centers geared toward women are already in place in India and Pakistan (Symington 2013). Both low-tech and high-tech innovations are also needed to help maintain older individuals' independence, dignity, and quality of life; low-cost and readily available versions of adaptive devices and aids, such as walkers, hearing aids, reading glasses and magnifiers, and grab bars present another form of technology solution.

Additionally, infrastructure in India needs to be elderly and handicapped friendly. As India continues to modernize its infrastructure, designing spaces for an aging population will involve building structures, adapting transportation, and implementing services that meet the needs of older adults and that address the principles of inclusivity, accessibility, and connectivity (World Health Organization 2007). This effort has started with Kolkata, Udaipur, and New Delhi becoming members of the WHO Age- 
Friendly World Global Network (Sinha 2012, World Health Organization Centre for Health Development 2015), a network committed to sharing best practices in urban healthy aging and promoting age-friendly infrastructure components such as accessible buildings and public transit, customer service that is friendly to older adults, and appropriate public places for walking and resting (World Health Organization 2007). With both urban and rural environments that often pose major mobility challenges to older adults and persons with disabilities, more Indian states and cities need to realize the importance of a built environment accessible to the aging population.

\section{2 - Women's and Gender Issues}

With an increasingly female and disproportionately vulnerable aging population, India must also implement programs and policies that ensure gender equity for older adults and healthy and secure aging for women and men. As discussed previously, technology has the potential to be a key asset in improving health care access for older adults and adult women. Call center and m-health services could also be expanded to cater specifically to the needs of older adult women, whose specialized health concerns may include female cancers, incontinence, and health issues associated with menopause.

While all older-adult health services must take women's needs into account, special attention must also be paid to India's growing population of older widowed women, who may suffer from greater rates of morbidity and engage less frequently in health-seeking behaviors than their male counterparts. While India has made strides toward ensuring the overall rights and dignity of widowed females, the government must continue to combat discrimination against widows, while expanding and ensuring the smooth administration of programs that help to ensure their financial security.

Finally, to ensure the financial security and independence of older women, regardless of their marital status, India must also make sure that laws ensuring women's property and inheritance rights are upheld and enforced. The country must also continue its progress in promoting the education of women and girls and encouraging female workforce participation, so that future generations of older adult women can become more politically empowered and depend less on husbands or families for their income.

\section{3 - Income Security Issues}

To improve income security for all its aging individuals, India needs to revise its retirement and pension policy to accommodate the country’s changing demography (Bloom and McKinnon 2014). A recently announced amendment to the national pension policy that extends the opportunity to receive pension benefits to all age-eligible adults regardless of employment or sector status is a first step toward an inclusive retirement and pension policy (Government of India 2015). As of the end of 2015, however, the Atal Pension Yojana Scheme-the portion of the plan that is specifically targeted to unorganized-sector workers - had only one million subscribers in the country, far short of the program's December goal of 200 million enrollments. Although the plan has been well publicized and monthly contribution levels begin at just INR 42 (about US\$0.60), it remains difficult to convince to lower-income and low-financialliteracy households of the importance of investing for retirement when day-to-day needs are much more pressing (Seth 2015). New or innovative schemes may be necessary to incentivize higher levels of retirement savings; much ground remains uncovered in restructuring social policies for the elderly in India. 
With rising health care costs, India's older adults must also be cushioned from the shocks of catastrophic health care expenditures. The need for readily available health care, including care for older adults, has been on the Indian government's radar for quite some time. Recommendations for publicly financed health insurance and provision of free drugs and diagnostic services are a part of India's 20122017 five-year plan, and in January of 2015 the new government's Finance Ministry released a draft National Health Policy (NHP) that states that "India would need to develop its own cost effective and culturally appropriate approach [...] to addressing the health and care needs of the elderly," which necessarily includes community and family support and meets the need for palliative and end-of-life care. It also increases provision of national tax revenue to individual states and devolves responsibility for health care program design and delivery to state governments (Government of India 2015, Reddy 2015). However, due to resource constraints, the government has drastically cut back on proposed spending for the plan, leaving these "national health assurance” provisions in doubt (Kalra 2015).

Finally, as discussed previously, declining levels of familial support among the elderly over the past decade remain a serious concern. In 2007, the government passed the Maintenance and Welfare of Parents and Senior Citizens Act, which allows adults 60 and older who are "unable to maintain" themselves to bring legal action against adult children or grandchildren who fail to provide them with such basic necessities as housing, food, clothing, and medical care (Government of India 2007, Sivaramakrishnan 2014). While this Act codifies the basic rights of older adults-it is particularly germane to vulnerable sub-populations, such as widows and low-income individuals - and provides a legal backbone to a faltering social order. It is also difficult to enforce, contains no assurances for childless adults, and does not address what, if any, are the responsibilities of the Indian government toward its aging citizens. Such family-centered social welfare measures must be complemented and supported by appropriate government initiatives such as a robust pension system and health care delivery.

\section{Conclusion}

India faces unprecedented population aging due to lengthening lifespans and dropping fertility. This demographic shift poses massive and complex challenges to Indian society in the form of a rising burden of noncommunicable diseases, a vulnerable female-heavy older adult population, a changing family structure, and a lack of a social safety net. Successfully addressing these challenges, while certainly far from impossible, will require equally complex and ambitious changes and innovations in health, fiscal, and social policies. 


\section{Bibliography}

(1991). United Nations Principles for Older Persons. United Nations, United Nations Human Rights, Office of the High Commissioner.

Agrawal, G. and K. Keshri (2014). "Morbidity patterns and health care seeking behavior among older widows in India." PLoS One 9(4): e94295.

Alam, M., et al. (2012). Report on the Status of Elderly in Select States of India, 2011. New Delhi, India, UNFPA India.

Arokiasamy, P., et al. (2012). Longitudinal aging study in India: Vision, design, implementation, and preliminary findings. Aging in Asia: findings from new and emerging data initiatives. J. P. Smith and M. Majmundar. Washington, D.C., The National Academies Press: 36-74.

Arokiasamy, P. and S. Yadav (2014). "Changing age patterns of morbidity vis-a-vis mortality in India." Journal of biosocial science 46(04): 462-479.

Bloom, D. E., et al. (2014). Economics of Non-Communicable Diseases in India: The Costs and Returns on Investment of Interventions to Promote Healthy Living and Prevent, Treat, and Manage NCDs. Geneva, World Economics Forum, Harvard T.H. Chan School of Public Health.

Bloom, D. E., et al. (2014). Longitudinal Aging Study in India: Biomarker Data Documentation. Boston, Harvard University Program on the Global Demography of Aging.

Bloom, D. E., et al. (2010). "Economic security arrangements in the context of population ageing in India." International Social Security Review 63(3-4): 79-97.

Bloom, D. E. and R. McKinnon (2014). The design and implementation of pension systems in developing countries: issues and options. International Handbook on Ageing and Public Policy. S. Harper and K. Hamblin. Cheltenham, UK, Edward Elgar: 108-130.

Cimperman, M., et al. (2013). "Older Adults' Perceptions of Home Telehealth Services." Telemed J E Health 19(10): 786-790.

Desai, S., et al. (2015). India Human Development Survey (IHDS). University of Maryland and National Council of Applied Economic Research. Ann Arbor and New Delhi, Inter-university Consortium for Political and Social Research.

Dey, S., et al. (2012). "Health of the Elderly in India: Challenges of Access and Affordability." Aging in Asia: Findings from new and emerging data initiatives. Panel on policy research and data needs to meet the challenge of aging in Asia, JP Smith and M. Majmundar, Eds. Washington, DC: The National Academies Press: 371-386.

Express News Services (2015). Government plans two national centres for the elderly. Indian Express. New Delhi, India. 
Fries, J. (1980). "Aging, natural death, and the compression of morbidity." The New England Journal of Medicine 303(3): 130-135.

Giridhar, G., et al. (2014). Introduction. Population Ageing in India. G. Giridhar, K. M. Sathyanarayana, S. Kumar, K. S. James and M. Alam. Delhi, Cambridge University Press: xvii-xxvi.

Government of India (2005). The Hindu Succession (Amendment) Act, 2005. Government of India. New Delhi. 39.

Government of India (2007). Maintenance and Welfare of Parents and Senior Citizens Act, 2007. 56/2007. Government of India. New Delhi, The Gazette of India.

Government of India (2011). "Census of India 2011." 2015, from http://censusindia.gov.in/.

Government of India (2013). Sample Registration System Statistical Report, 2011. C. Chandramouli. New Delhi, Office of the Registrar General, Ministry of Home Affairs.

Government of India (2015). "Appendix SRS Based Life Table." 2015, from http://www.censusindia.gov.in/vital_statistics/Appendix_SRS Based_Life_Table.html.

Government of India (2015). Atal Pension Yojana. D. o. F. Services. New Delhi.

Government of India (2015). Draft National Health Policy 2015. New Delhi.

Government of India (2015). "An Integrated Programme for Older Persons." 2015, from http://socialjustice.nic.in/ipop.php.

Government of India (2015). "Schemes and facilities for the older people." 2015, from http://www.oldagesolutions.org/facilities/schemesmain.aspx.

Government of India Press Information Bureau (2010). "National programme for prevention and control of cancer, diabetes, cardiovascular diseases, and stroke (NPCDCS) approved." 2015, from http://pic.nic.in/newsite/erelease.aspx?relid=63087.

Institute for Health Metrics and Evaluation (2014). Global Burden of Disease. Seattle, IHME, University of Washington.

International Diabetes Federation (2012). Diabetes Atlas. Brussels, International Diabetes Federation.

Jha, P., et al. (2011). "A Rational Taxation System of Bidis and Cigarettes to Reduce Smoking Deaths in India." Economic and Political Weekly 46(42): 44-51.

Joshi, S. R., et al. (2012). "Prevalence of diagnosed and undiagnosed diabetes and hypertension in Indiaresults from the Screening India's Twin Epidemic (SITE) study." Diabetes technology \& therapeutics 14(1): 8-15.

Kadoya, Y. and T. Yin (2012). Widow discrimination and family care-giving in India. Osaka, The Institute of Social and Economic Research (ISER), Osaka University. 
Kalra, A. (2015). Exclusive: Modi government puts brakes on universal health plan. Reuters. New Delhi, Thomson Reuters.

Lakhan, R. and O. Ekundayo (2015). "National sample survey organization survey report: An estimation of prevalence of mental illness and its association with age in India." Neurosciences in Rural Practice 6(1): 51-54.

Mani, M. (2005). "Experience with a program for prevention of chronic renal failure in India." Kidney International 67(Suppl): 75-78.

Patel, V., et al. (2010). "Effectiveness of an intervention led by lay health counsellors for depressive and anxiety disorders in primary care in Goa, India (MANAS): a cluster randomised controlled trial." Lancet 376(9758): 2086-2095.

Pati, S., et al. (2014). "Non communicable disease multimorbidity and associated health care utilization and expenditures in India: cross-sectional study." BMC Health Services Research 14(451).

Reddy, K. S. (2015). "India's Aspirations for Universal Health Coverage." N Engl J Med 373: 1-5.

Reddy, V. B., et al. (2013). "Mental Health Issues and Challenges in Inda: A Review." International Journal of Scientific Research Publications 3(2): 1-3.

Sathyanarayana, K. M., et al. (2014). Living Arrangements of Elderly in India: Policy and Programmatic Implications. Population Ageing in India. G. Giridhar, K. M. Sathyanarayana, S. Kumar, K. S. James and M. Alam. Delhi, Cambridge University Press: 74-95.

Seth, D. (2015). Atal Pension Yojana likely to miss December target. Business Standard. New Delhi, Business Standard Pvt Ltd.

Sinha, K. (2012). Kolkata joins global network for age-friendly cities. The Times of India. New Delhi, India.

Sivaramakrishnan, K. (2014). "Aging and Dependency in an Independent Indian Nation: Migrant Families, Workers and Social Experts (1940-60)." Journal of Social History 47(4): 968-993.

Srinath Reddy, K., et al. (2005). "Responding to the threat of chronic diseases in India." Lancet 366(9498): 1744-1749.

Symington, A. (2013). Pakistan's women can now dial-a-doc. The Christian Science Monitor.

United Nations (2014). World Urbanization Prospects, the 2014 revision. United Nations Dept of Economic and Social Affairs Population Division. Geneva.

United Nations (2015). World Population Prospects: The 2015 Revision. United Nations Deptartment of Economic and Social Affairs Population Division. Geneva.

Uppal, S. and S. Sarma (2007). "Aging, health and labour market activity: the case of India." World Health and Population 9(4): 79-97. 
World Bank (2015). World Development Indicators. Washington, D.C.

World Health Organization (2007). Global age-friendly cities: A guide, World Health Organization.

World Health Organization (2009). WHO report on the global tobacco epidemic, 2009: implementing smoke-free environments. Geneva, World Health Organization.

World Health Organization (2016). "WHO Global Strategy and Action Plan on Ageing and Health." from http://who.int/ageing/global-strategy/en/.

World Health Organization Centre for Health Development (2015). "Age-friendly cities." from http://www.who.int/kobe centre/ageing/age friendly cities/en/.

Wu, F., et al. (2015). "Common risk factors for chronic non-communicable diseases among older adults in China, Ghana, Mexico, India, Russia and South Africa: the study on global AGEing and adult health (SAGE) wave 1." BMC Public Health 15(88): 1-13. 